\title{
Krzysztof Grzegorzewski*
}

(iD) https://orcid.org/0000-0001-6862-1290

\section{Rhetorical strategies in the anti-alcohol propaganda of Polska Kronika Filmowa}

\section{Introduction}

The themes of alcohol and alcoholism were common in the propaganda campaigns of the People's Republic of Poland (PRL) throughout all four decades of its existence. Yet, quite obviously, the propaganda devoted to the issues were only a façade. In his monograph entitled Historia pijaństwa w czasach PRL, Krzysztof Kosiński concluded:

In the 1950s, the network of the spirit trade (mainly vodka; beer and wine could be bought in ordinary grocer's shops) continued to expand. By the end of the decade, the number of outlets selling spirits, including restaurants with a licence to sell spirits, exceeded 39,800. It was decreased upon the introduction of the Anti-Alcohol Law of 1959, though the number again increased in the second half of the 1960s. [...] In an OBOP survey of 1974, which was intended to emphasise the general availability of groceries, $78 \%$ of respondents indicated that vodka "was available always" (though $3,1 \%$ complained that "very often there was none"). ${ }^{1}$

The state monopoly on the spirit trade was restored by the authorities of the PRL in 1944, and they continued developing and reshaping it until 14 October 1948. The authorities also announced they would continue to upgrade and increase the

* Ph.D., University of Lodz, Faculty of Philology, Chair of Journalism and Social Communication; e-mail: krzysztof.grzegorzewski@uni.lodz.pl

1 K. Kosiński, Historia pijaństwa w czasach PRL, Wydawnictwo Neriton, Warsaw 2008, p. 33 [unless indicated otherwise, English versions of quotations were translated from Polish]. 
production of spirits. ${ }^{2}$ The main purpose of those activities was to ensure a steady regular income for the State Treasury. A summary of prices in 1959, as quoted by Kosiński, indicated that the selling price of alcohol was several times higher than the price of its production and distribution: the turnover tax was between $82,7 \%$ and $90,6 \%$. It was maintained at a similarly high level in the following years. In combination with the widespread availability of spirits and cheap wine (even when basic groceries were not available on the market), that resulted in the percentage of state income from the alcohol trade being, on average, around 10-11\% (in 1980 it even exceeded $14 \%)^{3}$ That level of income was so considerable that it was not possible to plan the state budget for the following years without considering it.

As Kosiński indicated, "not only the state budget benefited from the massconsumption of alcohol. It was also a source of major income for various institutions and circles $[. .$.$] generally referred to as the "alcohol lobby»."4 It included trade co-$ operatives, directors of some State Agricultural Farms (PGR), foreign trade and commerce companies, restaurants, and entrepreneurs. National councils also profited from it. And then, there was the "grey economy". ${ }^{5}$ Alcohol was exported to countries of the Socialist Bloc and outside it. However, the poor quality of the product and of its packaging posed major problems. When entities were not able to sell abroad the amounts of alcohol assumed by the planned economy, it was necessary to "increase the absorption" of the domestic market. ${ }^{6}$ A completely absurd solution when viewing it from the point of view of a modern free market economy (yet understandable in the economic reality of the PRL) was the sale of spirits made in Poland through the Pewex trade network, which was established in the mid-1970s. The vodka available there had an "export", i.e. better, quality than the spirits sold in normal off licences (and was considerably more expensive). The main purpose of those procedures, somewhat aside from "the increase of the absorption of the domestic market", was to gather the foreign currency savings of the citizens. The authorities also applied the social engineering device where Pewex customers were considered by other citizens as richer, and they eagerly flaunted that quality in their communities.

However, drunkenness in the PRL was not only economically conditioned. It was common in everyday life, in the documents of social life, and in the broadly understood cultural texts (in literature, film, posters, music lyrics, etc.) The themes of alcohol and drunkenness could be found in short stories by Polish writers and in films based on them (cf. novels by Leopold Tyrmand, short stories by Jan

2

3

4

5 Ibidem, pp. 525-581 (chapter Alkoholowa szara strefa).

6 Ibidem, p. 36. 
Himilsbach, films by the Himilsbach Maklakiewicz duo, or the cinema of social anxiety). Scenes with drunkards were common in Polish comedies and television series of the PRL (e.g. the productions directed by Stanisław Bareja). The reality of drunkards was framed in song by many bands, and in literature by poets and prose writers. Alcohol appeared in the biographies of artists (e.g. those of Z. Hołdys, Z. Laskowik), in the stories of actors, comedians, and stage performers. Apparently, alcohol was consumed in large amounts by state officials at all levels of power, drawing inspiration from the leaders and politicians of the "brotherly" USSR $^{7}$ who organised many lavish receptions and alcohol-soaked libations.

Thus, there emerges the boozy image of the whole society of the PRL, including the state's top echelon ${ }^{8}$ and with their support.

\section{Selection of the material}

All of the facts mentioned above indicate that anti-alcohol propaganda of that time could have been treated by the authorities only as a tool for a cynical distortion of reality. That was also the purpose of the content developed by Polska Kronika Filmowa [Polish Film Chronicle], which was established in 1944; which had a diverse use in different periods in the history of the PRL, depending on the changing influence the authorities had over PKF and the applicable policy towards the editorial team at individual periods. When studying the history of PKF, Marek Cieśliński identified nine periods:

1) formation of the principles of the information weekly (1944-1948),

2) Stalinist indoctrination (1949-1954),

3) the thaw (1955-1957), including, in particular, the moment of the Polish October,

4) artistic explorations and election-campaign-oriented satisfaction of the expectations of the authorities (1958-1970),

5) propaganda of success (1971-1980),

7 Cf. S.S. Montefiore, Stalin. Dwór czerwonego cara, trans. M. Antosiewicz, Wydawnictwo Magnum, Warsaw 2004; W. Taubman, Chruszczow. Człowiek i epoka, trans. Ł. Witczak, Wydawnictwo Bukowy Las, Wrocław 2012.

8 One exception was the cabinet of Wojciech Jaruzelski, who avoided alcohol and did not allow it to be served during receptions or celebrations (apart from having the proverbial glass of wine). The general's associates (J. Urban, W. Zakrzewski, and army officials), as well as L. Kowalski, his biographer, mentioned his aversion to alcohol. Jaruzelski himself in documentaries in which he appeared used to state: "I despise drunkards." Cf. T. Zakrzewski, Byłem reporterem generała, Książka i Wiedza, Warsaw 2002; H. Piecuch, Byłem gorylem Jaruzelskiego, Oficyna Wydawnicza Reporter, Warsaw 1993; L. Kowalski, Jaruzelski. Generał ze skazq, Wydawnictwo Zysk i S-ka, Warsaw 2012. 
6) disorientation in the face of breakthrough systemic changes (1981-1989),

7) decline in the new economic reality (1990-1994).9

Of course, not in every period identified by the historian could one identity the relevant styles and modes of shaping information specifically in the content on alcohol. Nonetheless, there were some regularities which I shall indicate in the rhetorical text analysis. The analysis will apply to content devoted to the theme of alcohol included in the Propaganda PRL-u. Najzabawniejsze polskie kroniki filmowe series. ${ }^{10}$ Those are currently the most popular and the most accessible version of fragments of PKF chronicles, which are available on DVDs and VCDs. They can also be found on YouTube, where they have reached between 700 ooo and 1000 ooo views. ${ }^{11}$ Internet users and television viewers also have access to full broadcasts of PKF (broadcast after 2000 by the Kino Polska channel, in an individual form or as collections, aired on a regular basis and commented upon by Michał Ogórek, a comedian), though it is clear that the indicated edition was the most common in modern Poland.

Discs with the chronicle include a total of 11 features devoted to the theme of alcohol: Wódka (turn of the 1950s; edition not specified); Jubileusz (as above); Pije Kuba..., (as above); Wóda! (35/57); Akcja bimber (49/58), Święte krowy (the 1960s, not specified), Wstap na piwko na przeciwko (16/68), Małe jasne (45A/72), Ale suszy (18B/78), Salonowa edukacja (8/85), Pod osłona nocy (50/84). Those usually constituted fragments of entire editions of PKF from specific years. They can be defined as mini-reportages or film commentaries. ${ }^{12}$ Sometimes, however, series editors decided to include film content developed separately by the editorial team of PKF without specifying the date when it was produced, only assigning it to a decade). In terms of themes, those could be categorised as follows:

a) consumption of alcohol and drunkenness;

b) drinking alcohol at work and its consequences;

c) moonshine production and speculation.

9 M. Cieśliński, Piękniej niż w życiu. Polska Kronika Filmowa 1944-1994, Wydawnictwo Trio, Warsaw 2006, p. 144.

10 Cf. Propaganda PRL-u. Najzabawniejsze polskie kroniki filmowe, Wydawnictwo Wprost i Grube Ryby 2006, discs 1-8.

11 Cf. https://www.youtube.com/watch?v=SmrwH7CVI8o\&t=6s and https://www.youtube.

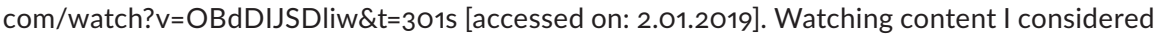
a viewing from start to end.

12 In terms of genre, the content mostly matched the criteria of a column/commentary ['felieton' in Polish] as defined by Edward Balcerzan. Cf. E. Balcerzan, "W stronę genologii multimedialnej", [in:] Polska genologia literacka, eds. D. Ostaszewska, R. Cudak, Wydawnictwo Naukowe PWN, Warsaw 2007, pp. 269-287. 
From the point of view of the previously mentioned alcohol policy of the PRL, the true intentions of the senders of the texts seemed to had been conveyed by two features in the third category: Akcja bimber [Operation moonshine] and Pod ostona nocy [Under the cover of night]. Those mainly differed in terms of the style of linguistic expression. While the first one, from the late-1950s, displayed a clearly moralising approach (though by using typical slogans and designators, e.g. "moonshine, the grim social detriment"), the other, recorded in the 1980s, had a clearly sarcastic tint (the rumblings of drunkards in the background and the stychomythia: "Gdzie pędzisz? U kolegi na siódmym piętrze!" [the Polish word "pędzić" can mean either "to rush somewhere" or "to produce moonshine", hence the humorous effect in the question and answer combination: "Where are you rushing to?/Where do you distil?" "To/At my friend's place on the seventh floor!"). The topic of moonshine production was presented in the material in a condescending manner as yet another problem of the declining PRL.

However, from the research perspective, what seems most interesting is to find the answer to the question: how was propaganda content intended to distort reality, and divert people's attention from it, developed? What devices and tricks were used to influence, or maybe just create the appearance of having influence on, the mass audience? The analysis, in this short text due to space limitations, covered four selected reports: Wódka (Socialist realism), Wstą na piwko na przeciwko ("minor stabilisation"), Ale suszy... (Edward Gierek's decade), and Salonowa edukacja (the decline of the PRL in the decade of Wojciech Jaruzelski's government). Those were representative for the identifiable periods of the PRL ${ }^{13}$ and they indicate the changing styles of PKF as defined by Cieśliński. ${ }^{14}$

\section{Tools for analysis}

In the study of the verbal and audio-visual layers of the content, I decided to apply three methods of rhetorical text analysis: the metaphorical method (which examines the application of tropes and figures), the neo-rhetorical method (which focusses on a text's argumentative apparatus), and the political method (which consists of identifying ideological elements in a text)..$^{15}$ In my analyses, I used both the tools

13 Cf. A.L. Sowa, Historia polityczna Polski 1944-1991, Wydawnictwo Literackie, Krakow 2011.

14 M. Cieśliński, op. cit., p. 144; the author devoted individual chapters of the study to individual periods, defining them in stylistic and factual terms, and by studying the influence of PRL authorities and censorship on the editorial team of PKF based on surviving documents.

15 J.Z. Lichański, "Retoryka a/i media: próba określenia pól wspólnych", [in:] Styl - dyskurs - media, eds. B. Bogołębska, M. Worsowicz, Łódź 2010, pp. 383-396. 
of classical rhetoric, and of modern rhetoric. ${ }^{16}$ The audio-visual content created by Polska Kronika Filmowa, which consisted of not only reporting shots, but also the distinctive music, text, and even the persuasive voice of the readers, changing throughout the decades, could, in fact, be treated as a rhetorical collective entity and, as such, be examined similarly to television political shows. ${ }^{17}$ That means the application of the tools available in the studies of persuasion and manipulation ${ }^{18}$, manipulative discrediting, and propaganda. ${ }^{19}$ Apart from the content of the audiovisual pieces, the interpretation of the texts by the readers had a major influence. The study of the notion of communication prosody by Anita Szwajkowska proved most useful. ${ }^{20}$

The most common form of PKF's content was a film illustrated with music and the voice of the reader reading a text. Content in the form of the so-called setka (one hundred) was rare initially. It started appearing significantly more often in the 1970s. By the end of its existence, PKF produced content similar in terms of structure to the modern reporter pieces in the main editions of news shows. ${ }^{21}$ However, the chronicles chosen for the analysis were mainly a combination of images, music and text read by a reader.

\section{Analysis of the reports}

\section{Wódka22}

The report from the socialist realism era opened with an ironically sounding commentary by Andrzej Łapicki: "Zabawna ta gazetka, co? Jestem osłem, co się zowie, piję wódkę na budowie!” [This brochure is amusing, isn’t it? I am an ass, day

16 Cf. Ch. Perelman, Imperium retoryki, trans. M. Chomicz, Wydawnictwo Naukowe PWN, Warsaw 2004.

17 Cf. K. Grzegorzewski, Homo rhetoricus w telewizyjnym dziennikarstwie politycznym (programy z lat 2005-2007), Wydawnictwo Uniwersytetu Łódzkiego, Łódź 2014.

18 E.g. Mechanizmy perswazji i manipulacji, eds. G. Habrajska, A. Obrębska, Wydawnictwo Uniwersytetu Łódzkiego, Łódź 2007; M. Karwat, Sztuka manipulacji politycznej, Wydawnictwo Adam Marszałek, Toruń 2001.

19 Cf. A. Pratkanis, E. Aronson, Wiek propagandy. Używanie i nadużywanie perswazji na co dzień, trans. J. Radzicki, M. Szuster, Wydawnictwo Naukowe PWN, Warsaw 2005; C. Bredemeier, Czarna retoryka. Siła i magia języka, trans. J. Miron, Wydawnictwo Studio Emka, Warsaw 2007; B. Dobek-Ostrowska, J, Fras, B. Ociepka, Teoria i praktyka propagandy, Wydawnictwo Uniwersytetu Wrocławskiego, Wrocław 1997.

20 A. Szwajkowska, "Wstęp do prozodii komunikacyjnej", [in:] Rozmowy o komunikacji 6, ed. G. Habrajska, Łódź 2013, pp. 117-166.

21 Cf. W. Godzic, Telewizja i jej gatunki. Po Wielkim Bracie, Universitas, Krakow 2004.

22 Propaganda PRL-u..., disc 1 - the 1940s/50s. [Vodka]. 
and night, who drinks vodka at the construction site!] The words were illustrated with workers dressed in vatniks grinning while pointing to a poster with an information brochure inserted in it. The slogan itself, just like the entire poster, was very simple in terms of the message, lacking any sophisticated rhetorical devices in the text layer, and not leaving much to interpretation in the visual layer: it presented the hunched figure of a drunkard with a wry face. The beginning, structured thus, virtually excluded any intellectual independence of viewing. Its authors communicated with the audience using directly formulated orders, bans and categorical statements: "Spójrz na tę dziewczynkę. Popatrzcie na te dzieci! To dzieci alkoholików" [Look at this girl. Look at these children! They are children of alcoholics] shouted the reader commenting on images from an orphanage or a psychiatric hospital. The show offered a simple and unequivocal classification, the over-simplified black-and-white evaluation typical for totalitarian systems: all children of drunkards are either sick or mentally deficient. The audience was not offered any statistics, figures or other evidence (though sometimes such elements were used by PKF).

What is interesting in the show is the role of the questions posed in it: "Czy chcesz skazać swoje dziecko na kalectwo, na epilepsję, na niedorozwój umysłowy?” [Do you wish to sentence your child to being a cripple, or to suffering from epilepsy, or mental retardation?] Those were fundamentally rhetorical. They were intended to amplify the previous message and emphasise for the audience the consequences of drunkenness and their inevitability. NB: in contemporary public discourse, it would be unacceptable and offensive to use such terms as "mental retardation" or "cripple" (in Polish, the word "kaleka" [a cripple] functions as a cacophemism or even an insult ${ }^{23}$ ). To further amplify the message and make it even more obvious, its author used simple emotionally-loaded expressions in the form of slogans: ${ }^{24}$ "Alkohol to wróg społeczeństwa! Alkohol niszczy człowieka, jego organizm i jego wolę." [Alcohol is the enemy of the people! Alcohol destroys man, his body and will] At the level of content mechanisms, the authors used the socialist realism figure of the enemy in reference to the chemical substance personified for that end, with the concurrent hyperbole (alcohol is the enemy not of a person, but of the entire society).

23 Examples of that could be found in the social-awareness campaigns for the mentally disabled conducted since 2004, e.g. "Niepełnosprawni intelektualnie - pełnosprawni w pracy" [Intellectually disabled yet fully able to work] or the media reaction to what Janusz KorwinMikke, a Polish extreme right politician, said in September 2012 comparing the Paralympic Games to "szachy dla debili" [chess for retards]. Vide https://wiadomosci.dziennik.pl/opinie/ artykuly/403217,korwin-mikk-obraza-paraolimpijczykow-moze-szachy-dla-debili.html [accessed on: 2.01.2019].

24 M. Kochan, Slogany w reklamie i polityce, Wydawnictwo Trio, Warsaw 2007. 
It is noteworthy that as a background to the text, there is a cutaway shot of a notice board at a health clinic and a moment later, a shot of the clinic's waiting room with patients waiting in line to a doctor's surgery. Just as the ominous slogans pass, PKF editors suggested the solution to the problem to the audience: the PRL operated "poradniami przeciwalkoholowymi, które pomagają w zwalczeniu tego straszliwego nałogu" [anti-alcohol clinics, which help in fighting this terrible addiction]. The show's audience was supposed to be convinced that the state had the power and means for the fight, and that it could counter that social calamity. The use of such arguments helped build the image of a state which was strong yet caring, resourceful, and capable of combating various hazards. The notion of alcohol, already amplified (verging on farce), as the enemy of society was used to paint the extent of the threat that needed to be combated.

The fact that the argumentation was ideological in nature is visible in the following quotes: "Rozpijały społeczeństwo rządy przedwojenne, alkohol był w rękach okupanta hitlerowskiego narzędziem do wyniszczania narodu. Dziś alkohol to broń w rękach wroga klasowego." [Pre-war governments induced society to drinking, in the hands of the Nazi occupation forces alcohol was a tool for ravaging the nation. Today, alcohol is the weapon in the hands of the class enemy.] Further arguments about the destruction of family life and the increasing number of accidents, though obvious, lost their expressive power when faced with the coarse device of comparing pre-WWII governments to the Nazis and later to the class enemy. Through the use of a rhetorical syllogism, the broadcast suggested that pre-WWII intelligentsia, capitalists, landowners, the clergy, Home Army soldiers, and anyone opposing the communist system were just like the Nazis. The audience did not even have to make any conjectures about the enemies: they were often mentioned in other chronicles, and in various media content and culture texts. This time, though, they were accused of causing alcoholism, which, as Kosiński mentioned in his monograph, was mainly caused by the PRL authorities. The show closed with the slogan: "Walka z pijaństwem to obowiązek społeczny" [The fight against drunkenness is society's duty.] It framed the show: it cemented the message using the previously applied metaphor of war, so common in PRL propaganda.

In the visual layer, one could identify collective condemnation and ridicule, characteristic of the Stalinist era; the function was fulfilled by the workers laughing at the brochure. In the following scene, the mood changed: the audience saw mentally ill children with wry faces and the typical absent looks, intended to clearly indicate mental disability. Today, the use of images of children with psychological conditions for propaganda purposes would be considered unethical (with the exception of the already-mentioned social awareness campaigns or announcements by charities raising money for treatment or maintenance of disabled children). 
In the above-mentioned anti-alcohol clinic, aid was delivered in an efficient and respectful manner, i.e. completely contrary to the common image of the living conditions in the PRL as a social system. ${ }^{25}$ The doctor's office featured a young man wearing a clean white coat - shaved, his hair neatly organised and he was smart (a tie was clearly visible over the top of the coat) - filling out a patient chart with a professional facial expression. In front of him, there was a patient sitting confiding his health problems. In the same examination room, another doctor (older, experienced) examined the abdomen of another patient. The following shots presented a focussed nurse administering an injection, and a smiling relaxed patient stretching out his arm with trust. The sequence of the images formed an obvious course of events: a trivial poster, a serious social problem and an effective cure for the evil: patients in a well-organised line, competent doctors examining them, and, finally, remedies in the form of medical treatment.

The rhetoric devices applied there, be they linguistic, visual or even sound in the form of the pompous symphonic music common at that time, can only be evaluated as primitive. The applied metaphor of war, numerous hyperboles and the figure of the enemy were common in all the content of those times. Alcoholism itself was not a social phenomenon which could be framed in statistical data or even a cause and effect sequence. In the content, the author indicated only one cause and culprit: the class enemy.

\section{Wstąp na piwko na przeciwko $(16 / 68)^{26}$}

The broadcast was developed in the final moments of the "little stabilisation"; it was shot after the events of March 1968. The difference is evident, e.g. in the choice of music, which used to be filled with pathos, sadness or exaltation, but in this show it is amusing, cheerful and lively, performed by an entertainment or jazz band contemporary for the Chronicle. ${ }^{27}$ It was a reflection of a general trend present in the musical illustration of PKF at that time. In that way, it also heralded a departure from the moralising style of social awareness campaigns and the beginning of use of the comic convention.

"Nieodłączny element krajobrazu naszych miast i miasteczek! Duże jasne na stojaka, najczęściej jako utrwalacz po ćwiartce," - czyta Włodzimierz Kmicik. [An inseparable element of the landscapes of our cities and towns! A large beer while standing, usually as a fixer after half a pint of vodka] As early as the first

25 Such a depiction was offered many times in various culture texts, feature films in particular (cf. television series and comedies directed by S. Bareja).

26 Propaganda PRL-u..., disc 5 - the 1960s, part 2 [Step in for a beer next door].

27 Similar music was also used in the comedy Nie lubię poniedziatku directed by Tadeusz Chmielewski (1971). 
two sentences, one can identify a wealth of rhetoric devices: first a stylisation of a explorer narration, followed by a lexicalised ellipsis ("duże jasne" [large beer]), a colloquialism ("na stojaka" [while standing] - it will come in handy later on), next a metaphor ("utrwalacz" [fixer]), and, finally, a common metonymy ("po ćwiartce" [after half a pint of vodka]). The verbal layer of the chronicle itself was already proof of a greater freedom in terms of the means of expression, and the evident artistic explorations and considerable skills of PKF creators at that time, as indicated by Marek Cieśliński. ${ }^{28}$ The language of expression became efficient, witty and convincing. The voice-over was accompanied by a clear visual suggestion: a beer stall (shot with the huge grey wall of an ugly tenement house in the background) appeared like an underworld meeting place; where someone would actually come after having drunk "half a pint".

The role of questions had also changed. "Co tam piszą w gazetach o alkoholizmie? Co alkoholizm, jaki alkoholizm, co to, już piwka nie można sobie strzelić?” [So, what's new in the papers about alcoholism these days? How alcoholism, what alcoholism, what, can't you have a beer anymore?] One should note Włodzimierz Kmicik's exceptional prosodic abilities; sometimes while delivering the voiceover he even displayed the skills of a parodist. The questions fulfilled the function of quasi-quotations: they were articulated in a stress line which sounded strong, resolute, common, stylised to imitate a person irritated at some newspaper ravings (the shot presented a crowd of men drinking beer straight out of bottles). A few seconds later an answer appeared to the quasi-quotation, delivered as if sneeringly and with emphasis on the final word, stressed with a derisive twitch to the voice: "Bo też w Polsce piwo służy nie co picia, lecz do upijania." [Because in Poland beer is not used for drinking, but for getting drunk] The statement thus organised becomes more emphatic, and, as a result, more convincing (though just as before, the audience would not find proof for the posed thesis). The derisive nature was amplified further in the film with an image of drunkards staggering or lying on the ground, and with the commentary: "najpierw na stojaka, potem na kiwaka, i wreszcie na leżaka" [first standing, then wobbling, and, finally, lying]. The author of the text referred to a popular colloquialism and matched to it later colloquial verbal nouns with a distinct epistrophe in the final syllables.

Similarly to previous films, that one also required a solution to the problem. "Teoretycy problemu twierdzą, że całe zło w budkach! Że należy otwierać chędogie piwiarnie, gdzie będzie się piło w sposób cywilizowany." [Theoreticians of the problem claim that the stalls are the source of the whole evil! That it is necessary to open neat and tidy beer rooms, where people would drink in a civilised manner.] The archaism of "chędogi" already suggests some spite, but what is most interesting is the realisation that there existed some theoreticians. They remained undefined, 
yet the phrase enabled the author to use the eristic device with an authority figure in the text. Therefore, the PKF film crew visited "taki kulturalny piwozdrój" [such a cultured beer fountain] - in this instance, the neological compound was used clearly in a sarcastic manner. The combination with the adjective "kulturalny" [cultured] and the actual shot could be treated as an oxymoron. The commentary: "Wszystko jak przed budką, tyle że pod dachem" [Everything like in front of the stall, only here it's indoors] displayed care for the rhythm of expression. The diagnosis, and the punch line of the broadcast, was also ironic in nature: "Naszym zdaniem metoda zadziała dopiero wtedy, gdy pijalni będzie więcej, niż budek!" [In our opinion the method will only work when there are more drinking rooms than stalls] as the displayed shots indicated the contrary. An interesting reversal of the situation occurred: in the previously discussed film, the authors had to prove the effectiveness of the PRL as a state fighting with alcoholism. In this case, however, state activities in the form of the opinions of the "theoreticians of the problem" were rather ridiculed - they were certainly not successful. The problem existed, it was identified, and condemned in a satirical manner, yet there was no solution.

The video layer mainly included men drinking beer, sometimes seriously intoxicated, yet there were no related drastic outcomes: mental illnesses, serious road accidents, etc. The authors of the feature placed emphasis on ethical issues. Those men, at various ages, sometimes young, were usually ill-mannered. They drank beer straight out of bottles, they thronged and pushed one another, their faces were twisted which indicated that they had just burped, or they suffered from drunkard's hiccups. There were many of them, just like the empty bottles. The manner of consuming beer itself was boorish, devoid of any culture of consumption - it was that lack that was the main theme of the show. It was further amplified by close-up shots of the faces of the beer drinkers. The ironic punch line was illustrated with a corresponding shot: a bulldog and its owner with fat pudding face skewed in a telling manner and 7-8 empty beer bottles in front of him, ostentatiously wiping his face with his hand and shrugging after drinking.

Clearly, the message of the chronicle was constructed in a much more careful manner: with evident elements of linguistic humour, irony or sarcasm even, with an intentional use of stylistic devices, rhythmical, read skilfully and professionally in prosodic terms. The shots were also selected in such a way as to amplify the comic effect. The resulting message was much more emphatic.

\section{Ale suszy... (18B/78) [Boy, he's thirsty]}

The report was created during the decline of Edward Gierek's decade, i.e. in a period of a serious and growing economic crisis caused by the state's policy. Various maladies of the system became evident then: numerous examples of careless 
management, excessive bureaucracy, and the overwhelming absurdity of how the economy functioned. The show began with a commentary read by Czesław Seniuch: "Powszedni dzień, godzina jedenasta. Po otwarciu sklepu monopolowego przy ul. Pustola w Warszawie tłoczno jak przed stacją z paliwem!" [A weekday, 11 a.m. After the off-licence in Pustola St. in Warsaw is opened, there are as many people there as at a petrol station] That seemingly neutral comparison indicated economic difficulties, in that case: with acquiring petrol. The words perfectly matched the shots: various vehicles arriving at the shop, mainly lorries and construction vehicles. Two devices stood out: the fact of placing the story in a specific place and time (to indicate the problem of consuming and abusing alcohol at work), and the fact of using shots of lorries carrying no load. PKF authors thus indicated yet another malady: the so-called "puste przebiegi" [empty rides]. The music used throughout the report (Light Cavalry by Franz von Suppe) was elevated, pompous, yet cheerful and maintained in the major scale, heralding some grand and important event. In combination with shots of lorry drivers drinking alcohol, it offered a comical effect. The reader's statements were similarly sneering and ironic: "Nie ma się co dziwić - przerwa śniadaniowa. Trzeba przecież kupić coś na pokrzepienie." [No wonder - it's lunch time. You obviously need to buy something for reassurance]

The author of the text carefully avoided using the word "alcohol" or any names of specific alcoholic beverages. Instead, there appeared "coś" [something] or "to" [that] pronouns functioning as euphemisms: "Ale będzie niespodzianka, kiedy chłopakom przywiesie się TO zamiast cementu" [Imagine the guys' surprise, when you get them THAT instead of cement]; "Nyska z zakładu pogrzebowego. Idziemy dopełnić smutnego obrzędu. Aaa, gdy się TO posiada, łatwiej będzie świadczyć usługi dla ludności!". [A van from a funeral home. We're going to fulfil the sorrowful rite. Oh, when you have THAT, it will be easier to provide services to the people!] In the final example, viewers could hear the reader's voice getting clearly sadder when talking about the "sorrowful rite", though the theatrical quality of the prosodic gesture could be sensed. His voice became immediately cheerful again when talking about alcohol. Further in the report, the reader went on: "Tuż obok zakładów i placów budowy taki sklep - cóż za wygoda!" [Such a shop right next door to industrial complexes and construction sites - imagine the convenience!] One could understand the text as an ironic preface to a solution which, though in a different context, had already been utilised in the free Poland by legally defining the acceptable distance of off-licences from public transport stations, schools, religious sites, etc. Further fragments of the commentary referred in a sarcastic manner to the slogans of the period of the propaganda of success: "Porządek i organizacja! Wszystko musi być na właściwym miejscu!” [Order and organisation! Everything must be in its place!] In the background, one could see a worker hiding three vodka bottles under his vatnik. Though there were some less successful inclusions (e.g. the "popój" neologism [act of 
drinking in a vulgar manner]), what stood out was the structuring of irony mainly through combining the verbal layer with the contrasting visual layer, thus achieving the comical effect resembling scenes from the film Miś by Stanisław Bareja.

The punchline had a clearly mocking nature: "To nic, że nie trzymamy pionu! Grunt, że domy, które się nieopodal buduje, mają proste ściany”. [It’s not a problem he can't stand straight! All that matters is that nearby houses have straight walls] The statement was clearly contrary to the everyday experiences of the residents of blocks of flats built in the PRL, in which both floors and walls were strikingly crooked. From the 196os, the editors at Polska Kronika Filmowa had reported on the botchery of builders; similar "maladies" were mocked in Polish comedy films and television series.

The visual communication was typical for the era of the propaganda of success: the set included many heavy vehicles like HGVs, lorries, delivery trucks, tractors and construction vehicles, which brought to mind the photographs with multiple tractors in a field, at some point mocked by Rudi Schuberth, a comedian, and the Poznań-based Tey comedy group. That setting was filled with workers drinking beer or vodka straight out of the bottle who would hide the bottles in any available pocket. The commentary saturated with ostentatious irony complemented the image presenting the problem in a comical and somewhat grotesque manner.

\section{Salonowa edukacja $(8 / 85)^{29}$}

The last of the analysed reports was developed halfway through the decade of Wojciech Jaruzelski's government, i.e. in the decline of the PRL and its almost total economic collapse. It was styled to resemble an official account of a celebratory event. Jerzy Rosołowski read: "Wspólnymi siłami kilku warszawskich hoteli Komitet Kultury Picia urządził pokaz i degustację napitków niskoprocentowych". [Through the joint efforts of several Warsaw hotels, the Committee for Civilised Drinking organised an event of display and tasting of low-proof beverages] All remaining passages were formulated in a similar official manner: the narration was impersonal, and it avoided the use of personal forms. Sometimes, it was combined with colloquialisms, a fact which was supposed to evoke a comical effect: " $Z$ dezaprobatą odniesiono się do wszelkich form odbijania przed przystąpieniem do konsumpcji, jak również samego aktu spożywania na tzw. rurę". [All forms of knocking the bottle prior to consumption were discouraged, just like the very act of consumption in the so-called pipe]

Other identifiable features of the official style included the numerous analytical structures, the use of lexis typical for higher Polish ("consumption" instead of "drinking", "prior" instead of "before", etc.) The style was used quite consistently, and 
the text acquired its rhetorical quality only after being combined with the images, as the report did include shots from the official event but they were intertwined with shots from a drinking den. When "zebrani krytyczni wyrazili się o wyrobach konkurencji" [the guests aired their critical remarks on the products of the competition], the report featured a shot of salicylic and birch spirit and windshield washer liquid. The following shot included a smartly dressed bartender preparing cocktails with condensed milk and very expensive liqueurs. The shot was contrasted with a still image of some people pouring Warka wine and Wistula vodka into a filthy bar mug (with the typical narrowing at the base) placed on a newspaper-covered board in a filthy room. The scene was combined with a commentary: "Uchwała jest otwarta na nowe idee koktailowe". [The official act is open to new cocktail ideas] Allow me to quote also the final fragment of the text: "Organ kultury picia, tygodnik Veto, stwierdza, że najskuteczniejszą drogą walki z pijaństwem jest uczenie rodaków picia kulturalnego. Nic to, że na razie ustami najwybitniejszych przedstawicieli." [The agency of civilised drinking, the Veto weekly, concluded that the most effective way of fighting drunkenness is to teach Poles how to drink in a civilised manner. No matter that, for now, it's through the lips of the most prominent representatives]

The entire report seemed to be a grotesque, verging on mockery. ${ }^{30} \mathrm{In}$ fact, it was proof of the almost complete detachment of the PRL authorities from reality. The characteristic counter-point construction was visible not only in the shots (a serious event with expensive alcoholic beverages contrasted with drinking cheap vodka, wine and industrial alcoholic liquids in the basest and most boorish of ways). It was also clearly marked by the music: the musical theme resembling a tango was supplemented with dissonant mixed electro-acoustic sounds, resembling the ramblings of a drunkard. Those were most prominent at the end of the report which featured a shot of staggering extremely drunk men. Juxtaposed with that, the final remark seems to be a sneer.

\section{Conclusions}

The four analysed shows somewhat captured the essence of the PRL system, starting with the Stalinist years all until the "agony of the system". ${ }^{11}$ Similar conclusions could be drawn by examining PKF shows devoted to other social matters (the editors had always maintained the official propaganda-guided tone when discussing

\footnotetext{
30 I was not able to prove the existence of Komitet Kultury Picia - it might have been concocted by the authors of the Chronicle. Tygodnik Każdego Konsumenta Veto [the Veto All Consumers' Weekly] did exist and it was circulated in 1982-1995. Vide https://pl.wikipedia.org/wiki/Veto_ (czasopismo) [accessed on: 3.01.2019].

31 A term by Hanna Świda-Ziemba. Cf. H. Świda-Ziemba, Młodzież PRL. Portrety pokoleń w kontekście historii, Wydawnictwo Literackie, Krakow 2010.
} 
political topics, though even in such shows one could find differences caused by the transformations in the language of the PRL propaganda). In terms of composition and the stylistic devices applied, the Stalinist years proved the most primitive and coarse. The rhetorical devices were unoriginal and predictable and on top of that they were imposing, and they violated ethical limits. During the October thaw, the editors of the Chronicle sought out new means of expression as well as a new idea for their presence within the public discourse. They found their way in the 1960 s. The commentary was inventive, often very well-edited, and it was often filled with cleverly applied tropes and figures and a sense of humour. They made sure the texts had their rhythm and dynamics; the illustration with images and music gave the impression of being thoughtful, it aligned with the verbal message well, and it was not rare that it complemented the message in a surprising manner. The 1970s, marked by the primitive propaganda of success and much greater compliance of the editors expected by the state, featured an accumulation of grotesque images which were caused by, on the one hand, the gigantomia typical of that time, and, on the other, the increasingly evident signs of various illnesses of the system, which heralded its erosion and impending disintegration (mainly in economic, but also social and political terms). In the 1980s, the period when PKF itself had considerable trouble with ensuring distribution and displaying their films, there appeared works visibly critical of the reality which surrounded Poles: saturated with irony or even blatant derision. Those reports could, paradoxically, seem the most pungent, which made them the most interesting in reception.

In factual terms, however, a completely opposite process existed. In the 1950s, PKF presented an image of the PRL where some maladies did exist, but the state's expected attitude of the society was supposed to be unequivocal: it was necessary to fight the enemy. In that fight, citizens could count on the effective socialist state which had the power and the resources (which it was able to use in a ruthless manner), but which, at the same time, was caring, efficient and convinced about the legitimacy of its actions. A decade later, in PKF films which featured a more relaxed and detached approach to the topic, the previously devised monolith began to show some cracks. The subtle irony of the authors of the Chronicle did not yet indicate a clear mocking of the state, though that did not mean that the Chronicle did not include some instances of lecturing. However, that was expressed in a different manner, following the principle of "teaching through amusement". During the period of the propaganda of success, the images that existed were grotesque. The propaganda system acted somewhat against itself: it showed the images of construction workers who were, mind you, a vital element of a major sector of the economy, i.e. the country's development and industrialisation, but who were also plagued by alcoholism. The authorities had absolutely no control over the situation. So, no wonder that the last of the analysed reports, though 
developed in an interesting and witty manner, proved the complete detachment of the authorities and the opinion-making elite from the reality of the PRL. The absurd resolution of a similarly absurd Committee for Civilised Drinking were the perfect examples of that. If one were to compare other Chronicles from that time (cf. Kronika malżeństwa, Życie na talony, Fantastycznie, or Polak przed zima), the extracted image would be that of a state in complete economic ruin, which was extremely inefficient and managed by authorities utterly hated and discredited in the eyes of the citizens. That image could no longer be saved by the broadcasts of Wojciech Jaruzelski's speeches, accounts of visits by "brotherly" countries or reports on the special teams of the Polish People's Army travelling throughout Poland. The propaganda of the PRL in decline, achieving results contrary to those intended, was a clear indication of the "agony of the system".

\section{Bibliography}

Balcerzan Edward, "W stronę genologii multimedialnej", [in:] Polska genologia literacka, eds. D. Ostaszewska, R. Cudak, Wydawnictwo Naukowe PWN, Warsaw 2007, pp. 269-287.

Bredemeier Karsten, Czarna retoryka. Siła i magia jezzka, trans. J. Miron, Wydawnictwo Studio Emka, Warsaw 2007.

Cieśliński Marek, Piękniej niż w życiu. Polska Kronika Filmowa 1944-1994, Wydawnictwo Trio, Warsaw 2006.

Dobek-Ostrowska Bogusława, Fras Janina, Ociepka Beata, Teoria i praktyka propagandy, Wydawnictwo Uniwersytetu Wrocławskiego, Wrocław 1997.

Godzic Wiesław, Telewizja i jej gatunki. Po Wielkim Bracie, Universitas, Krakow 2004.

Grzegorzewski Krzysztof, Homo rhetoricus w telewizyjnym dziennikarstwie politycznym (programy z lat 2005-2007), Wydawnictwo Uniwersytetu Łódzkiego, Łódź 2014.

https://www.youtube.com/watch?v=OBdDIJSDliw\&t=301s [accessed on: 2.01.2019]. https://www.youtube.com/watch?v=SmrwH7CVI8o\&t=6s [accessed on: 2.01.2019].

Karwat Mirosław, Sztuka manipulacji politycznej, Wydawnictwo Adam Marszałek, Toruń 2001.

Kochan Marek, Slogany w reklamie i polityce, Wydawnictwo Trio, Warsaw 2007.

Kosiński Krzysztof, Historia pijaństwa w czasach PRL, Wydawnictwo Neriton, Warsaw 2008.

Kowalski Lech, Jaruzelski. Generał ze skaza, Wydawnictwo Zysk i S-ka, Warsaw 2012. 
Lichański Jakub Z., "Retoryka a/i media: próba określenia pól wspólnych", [in:] Styl - dyskurs - media, eds. B. Bogołębska, M. Worsowicz, Łódź 2010, pp. 383-396.

Mechanizmy perswazji i manipulacji, eds. G. Habrajska, A. Obrębska, Wydawnictwo Uniwersytetu Łódzkiego, Łódź 2007.

Montefiore Simon S., Stalin. Dwór czerwonego cara, trans. M. Antosiewicz, Wydawnictwo Magnum, Warsaw 2004.

Perelman Chaim, Imperium retoryki, trans. M. Chomicz, Wydawnictwo Naukowe PWN, Warsaw 2004.

Piecuch Henryk, Byłem gorylem Jaruzelskiego, Oficyna Wydawnicza Reporter, Warsaw 1993.

Pratkanis Anthony R., Aronson Elliot, Wiek propagandy. Używanie i nadużywanie perswazji na co dzień, trans. J. Radzicki, M. Szuster, Wydawnictwo Naukowe PWN, Warsaw 2005.

Propaganda PRL-u. Najzabawniejsze polskie kroniki filmowe, Wydawnictwo Wprost i Grube Ryby 2006, discs 1-8.

Sowa Andrzej L., Historia polityczna Polski 1944-1991, Wydawnictwo Literackie, Krakow 2011.

Szwajkowska Anita, "Wstęp do prozodii komunikacyjnej”, [in:] Rozmowy o komunikacji 6, ed. G. Habrajska, Łódź 2013, pp. 117-166.

Świda-Ziemba Hanna, Młodzież PRL. Portrety pokoleń w kontekście historii, Wydawnictwo Literackie, Krakow 2010.

Taubman William, Chruszczow. Człowiek i epoka, trans. Ł. Witczak, Wydawnictwo Bukowy Las, Wrocław 2012.

Zakrzewski Tadeusz, Byłem reporterem generała, Książka i Wiedza, Warsaw 2002.

Krzysztof Grzegorzewski

\section{Strategie retoryczne w propagandzie antyalkoholowej Polskiej Kroniki Filmowej}

Streszczenie

Trzonem tekstu jest retoryczna analiza propagandy antyalkoholowej w przekazach Polskiej Kroniki Filmowej, produkowanej przez WFDiF. Autor wybrał cztery felietony z popularnej serii Propaganda PRL-u. Najzabawniejsze polskie kroniki filmowe i poddał je trzem typom analizy tekstu: metaforycznej, neoretorycznej 
oraz ideologicznej. Artykuł został wzgobacony o wiedzę w zakresie historii politycznej PRL, a także jej szczegółowe aspekty, jak historia pijaństwa w tej epoce. Autor uwzględnił również medioznawcze opracowanie na temat PKF, a także teorie w zakresie propagandy, perswazji i manipulacji.

Słowa kluczowe: perswazja, manipulacja, propaganda, film, kronika filmowa, dziennikarstwo, komunikacja masowa

\section{Rhetorical strategies in the anti-alcohol propaganda of Polska Kronika Filmowa}

Summary

The core of the text is a rhetorical analysis of the anti-alcohol propaganda in the films by Polska Kronika Filmowa produced by WFDiF. The author selected four reports from the popular series: Propaganda PRL-u. Najzabawniejsze polskie kroniki filmowe and analysed them using three types of textual analysis: metaphorical analysis, neo-rhetorical analysis, and ideological analysis. The article was complemented with facts from the political history of the People's Republic of Poland in some specific aspects, e.g. the history of drunkenness in that period. The author also included a media research study regarding PKF, as well as theories of propaganda, persuasion and manipulation.

Keywords: persuasion, manipulation, propaganda, film, newsreel, journalism, mass communication

Krzysztof Grzegorzewski - Ph.D., assistant professor at the Department of Journalism and Social Communication at the University of Lodz. He researches journalistic rhetoric and special types of journalism, including political journalism. He published a book called Homo rhetoricus in TV political journalism (programs in period 2005-2007) and a lot of scientific articles on rhetoric and media studies. He has lectured in several European countries, including Sweden, Norway, Latvia and Lithuania, Estonia and Bulgaria. He is also a radio deejay, music journalist and speaker and also political commentator. 